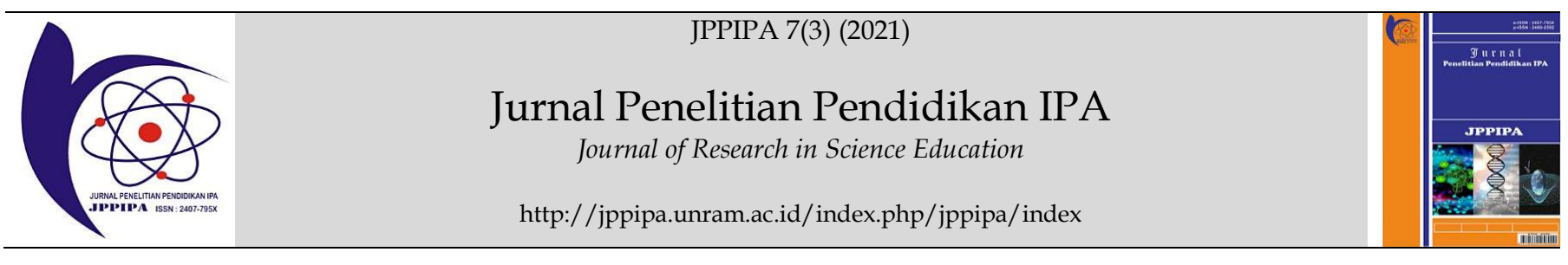

\title{
The Effect of Using e-module Model Problem Based Learning (PBL) Based on Wetland Environment on Critical Thinking Skills and Environmental Care Attitudes
}

\author{
Mohamad Nor Aufa1 ${ }^{*}$, Rusmansyah², Muhammad Hasbie ${ }^{1}$, Akhmad Jaidie $^{3}$, Amalia Yunita ${ }^{1}$ \\ ${ }^{1}$ Master of Natural Science Teacher Training, Postgraduate, Lambung Mangkurat University, Banjarmasin, Indonesia. \\ ${ }^{2}$ Chemistry Education, Faculty of Teacher Training and Science Education, Lambung Mangkurat University, Banjarmasin, Indonesia. \\ ${ }^{3}$ Accreditation Board for Schools/Madrasahs in South Kalimantan Province, Banjarmasin, Indonesia.
}

DOI: $10.29303 /$ jppipa.v7i3.732

\section{Article Info}

Received: May 4th 2021

Revised: July $4^{\text {th }}, 2021$

Accepted: July 7th, 2021

\begin{abstract}
This study aims to analyze the effect of using an E-module with a wetland environment-based PBL model on students' critical thinking skills and environmental care attitudes. This study was a quasi-experimental study with a non-equivalent posttest only control group design. The study population was 150 students, while the sample was selected by random sampling. The number of samples in this study was 64 students who were divided into two classes. The instrument used was a test, namely a question of critical thinking skills in the form of an essay and a non-test in the form of a questionnaire for environmental care attitudes. The collected data were analyzed by using Multivariate Analysis of Variance. The results showed that the significance of the three hypotheses was 0.000 , which means less than $0.05(0,000<0.05)$. So, it can be concluded that there is a positive effect of using the E-module with the PBL model on critical thinking skills and environmental care attitudes. The novelty of this study integrates the wetland environment in the learning process using teaching materials in the form of E-modules in the learning process of the topic of acid-base solutions on critical thinking skills and environmental care attitudes of students.
\end{abstract}

Keywords: E-module; PBL; critical thinking skills; environmental care; wetland environment

Citation: Aufa, M., Rusmansyah, R., Hasbie, M., Jaidie, A., \& Yunita, A. (2021). The Effect of Using e-module Model Problem Based Learning (PBL) Based on Wetland Environment on Critical Thinking Skills and Environmental Care Attitudes. Jurnal Penelitian Pendidikan IPA, 7(3), 401-407. doi:https://doi.org/10.29303/ippipa.v7i3.732

\section{Introduction}

The development of science and technology demands fundamental changes in the education system worldwide, including Indonesia, to produce a generation that can compete in overcoming the complexities of future life (Suryanti et al., 2018; Zulmaulida et al., 2018). Therefore, educators can apply the $21^{\text {st }}$ Century Learning Framework in science (especially chemistry), namely the Framework for 21st Century Learning (Hastuti et al., 2018; Redhana, 2019). This framework serves as a foundation of competencies that students must possess and master as a provision for successful careers in their future lives (Redhana, 2019), namely mastering learning and innovation skills (critical, creative, problem-solving, collaborative, communicative); life and career skills (responsible, social, tolerant, productive, adaptive, etc.); as well as skills using media, information, and technology (Redhana, 2019; Vlasta \& Jan, 2011). It is not enough for the generation of critical thinkers to master critical thinking skills and be responsible by giving attention 
and concern to human values and the surrounding environment (Wilson, 2016).

Critical Thinking Skills are one of the skills that students must have to deal with the complexities of future life. Critical thinking skills include cognitive competence (dissecting, analyzing, interpreting, examining, modifying, synthesizing, connecting, summarizing, making conclusions, generalizing) with personality competence (tolerant of ambiguity, independent thinking, having persistence, confidence, curiosity, motivated, dare to take different, reflective, creative risks and interact with each other constantly (Fahim \& Pezeshki, 2012; Sumarni et al., 2018).

Critical thinking skills are best understood as the ability of thinkers to take responsibility for their thinking (Fahim \& Masouleh, 2012) so that critical thinkers try to have good criteria and standards in assessing their thinking and using them to improve the quality of their thinking. Self-thinking or independent study (such as: setting goals, organizing environment and time, seeking help, and self-evaluation) is very important for students to be successful and meaningful in learning science, especially in the learning process of Chemistry.

But in fact, the critical thinking skills of students are still in the low and medium (Hasbie et al., 2018; Naparin et al., 2020; Ulfah, 2020). The study results are also in line with research conducted by (Anantyarta \& Sari, 2017; Prihartiningsih et al., 2016) which states that students' critical thinking skills are in a low category. This is because students still use teaching materials that emphasize the content dimension rather than the process and context dimensions. Moreover, the material presented in the teaching materials only appears in the form of concept definitions, a set of formulas, and exercises, making it difficult for students to develop critical thinking skills. According to (Rosnanda et al., 2017; Zekri et al., 2020), to improve and empower critical thinking skills, can use teaching materials in the form of modules. Modules are alternative teaching materials so that the learning process can be learner-centered and make it easier for students to find concepts and develop the learning process (Imanda et al., 2017; Kurniawan et al., 2018).

The epidemic period of the COVID-19 epidemic urged for distance education testing has rarely been carried out simultaneously before for all elements of education, namely students, teachers, and parents. Given that time, location, and distance are currently significant problems (Goldschmidt, 2020; Sun et al., 2020). This pandemic condition poses a challenge to all elements to keep classrooms active even though schools have been closed online learning by utilizing platforms in the form of applications, websites, social networks, and learning management systems (Bao, 2020; Basilaia
\& Kvavadze, 2020; Gunawan et al., 2020) so that an electronic/e-module-based teaching material can be developed with the help of the Professional 3D Pageflip application.

The important thing that needs to be considered in e-module development is the choice of a model/method because this is the main point so that the e-module developed is in accordance with the desired goals (Aufa et al., 2020; Sari \& Rachmawati, 2017). In this study, the e-module used is e-module with the Problem Based Learning (PBL) model because, according to several studies, the PBL model has a general goal of improving critical thinking skills, inquiry skills and problem-solving skills, and skills to learn independently (Ageorges et al., 2016; Birgili, 2015; Efendioglu, 2015; Klegeris et al., 2013; Temel, 2014).

However, the results of the meta-analysis research on the results of the 2006 to 2013 study of PBL model learning show that (1) it is very important to pay attention to the learning environment of students (2) the PBL model has not shown to be able to practice critical thinking skills maximally (Batdi, 2014). The PBL model suggests a perspective that the learning process in schools should be a laboratory for solving real-life problems (authentic problems). One of the topics of authentic problems that can be used as real/authentic problems presented in the PBL e-module is the wetland environment, one of South Kalimantan's local wisdom.

Wetlands are areas of brackish, swamp, peat, or water, whether natural or artificial, permanent or temporary (temporary), with flowing or still, fresh, brackish or salty water, including areas with seawater that is deep at high tide. Low (low tide) does not exceed 6 meters (Ramsar Convention). Utilization of the wetland environment in the authentic problem of the PBL model can improve critical thinking skills, creative, analytical, and environmental care (Lestari \& Projosantoso, 2016; Yarid \& Ariswan, 2016; Yunita \& Aufa, 2020; Zaini et al., 2020). In addition, the wetland environment can also foster love, conservation, and concern for the environment, especially the wetland environment as one of the local wisdom of South Kalimantan (Ibrahim et al., 2012).

Based on the above, the researcher wants to see the effect of E-module Problem Based Learning (PBL) based on Wetland Environment on Critical Thinking Skills and Environmental Care Attitudes on Acid-Base Solution Material for class XI SMA using the 3D Professional Pageflip application.

\section{Method}

This research is a quasi-experiment with a nonequivalent pretest-posttest control group design. This research is called a quasi-experiment because in 
determining the sample, individual randomization is not carried out but by drawing the whole classes with academic equivalence. This research was conducted at MAN 1 Banjarbaru City in class XI semester II of the academic year 2021/2022. The population in this study were all students of class XI MAN 1 Banjarbaru City in the academic year 2021/2022, totaling 150 students. The sample used in this study was selected using a random sampling technique. Based on the drawing that was carried out in all classes, two classes were chosen as samples, namely class XI-A and XI-C, with a total of 64 students. The two classes were then drawn again to determine the control group and the experimental group. Based on the results of the draw, class XI-C was selected to be an experimental group that was treated by applying the E-module PBL model based on wetlands, while class XI-C was used as a control class who would learn using textbooks commonly used in schools.

The variables in this study were the dependent variable and the independent variable. The independent variables in this study were the E-module PBL model based on wetlands and textbooks commonly used in schools. In contrast, the dependent variable in this study was critical thinking skills and environmental care. The critical thinking skills test instrument consists of indicators, name interpretation, analysis, evaluation, and inference (Facione, 2015). Environmental care attitude instruments consist of indicators of the physical environment, social environment, biological environment, and obstacles in the process of environmental care behavior.

Instrument testing was carried out at SMAN 3 Banjarmasin City in two classes, namely class XI MIA 2 and XI MIA 3, and involved 68 students as respondents. Before the field test was carried out, the instrument was tested by experts first by three experts. The expert test results showed that the instruments, both the critical thinking skills test and the environmental care attitude questionnaire, were appropriate for research instruments. The results of the analysis of the validity and reliability of the critical thinking skills test of 16 items that meet the requirements to become an instrument are 12 items. In contrast, the environmental care attitude questionnaire from 40 questionnaires that meet the requirements to become an instrument is only 37 questionnaires.

Data collection in this study was carried out by means of test methods, questionnaires, and documentation. The critical thinking skills test instrument and environmental care attitude questionnaire were given before treatment (pretest) and after being given treatment (posttest). The data from this study were analyzed by using Multivariate Analysis of Variance (MANOVA). The calculation of the improvement in critical thinking skills and environmental care attitudes is analyzed based on the normalized score gain from the pretest and posttest results.

The data analysis technique in this research is descriptive statistics and inferential statistics with variance analysis techniques, namely Multivariate Analysis of Variance (MANOVA). Descriptive analysis techniques are used to describe the results of the students' pretest and posttest. Before testing the hypothesis with the MANOVA test, first, the data distribution normality, variance homogeneity, and data collinearity test were conducted with the help of the SPSS 26.0 for the windows program. The test results show that the data is normally distributed.

\section{Result and Discussion}

The results of the MANOVA analysis obtained the value of $\mathrm{F}=3798.463$ with a significance value on Pillai's Trace, Wilks'Lambda, Hotelling's Trace, and Roys's Largest Root is 0.000 . This value is smaller than the significance level of 0.05 ( $\mathrm{p}<0.05$ ). Thus $\mathrm{HO}$ is rejected, and H1 is accepted. The summary of the test results with the MANOVA analysis is presented in Table 1 below and figure 1 e-module with a wetland environment-based PBL model.

Table 1. Result Multivariate Tests

\begin{tabular}{lllll}
\hline Effect & & Value & $\mathrm{F}$ & Sig. \\
\hline Intercept & Pillai's Trace & .992 & $3798.463 \mathrm{~b}$ & .000 \\
& Wilks' Lambda & .008 & $3798.463 \mathrm{~b}$ & .000 \\
& Hotelling's Trace & 116.876 & $3798.463 \mathrm{~b}$ & .000 \\
& Roy's Largest & 116.876 & $3798.463 \mathrm{~b}$ & .000 \\
& Root & & & \\
& Pillai's Trace & .717 & $82.250 \mathrm{~b}$ & .000 \\
& Wilks' Lambda & .283 & $82.250 \mathrm{~b}$ & .000 \\
& Hotelling's Trace & 2.531 & $82.250 \mathrm{~b}$ & .000 \\
& Roy's Largest & 2.531 & $82.250 \mathrm{~b}$ & .000 \\
& Root & & & \\
\hline
\end{tabular}

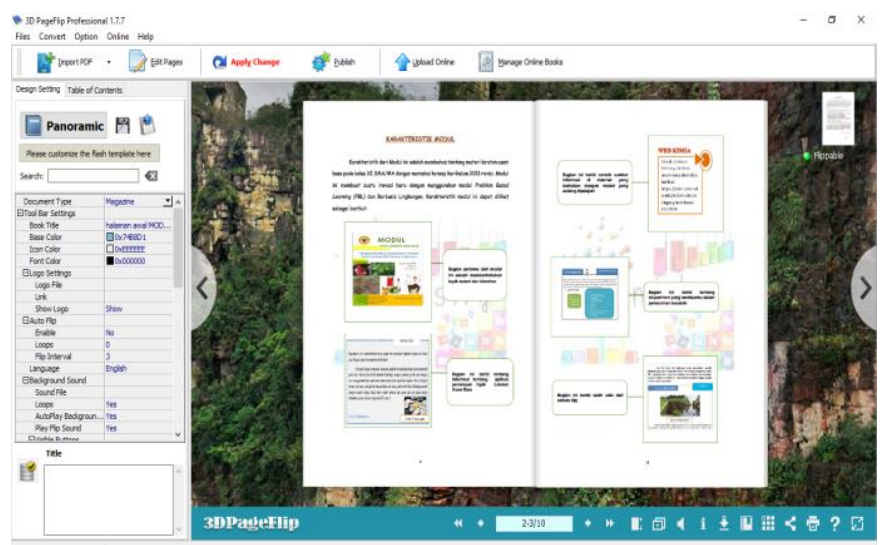




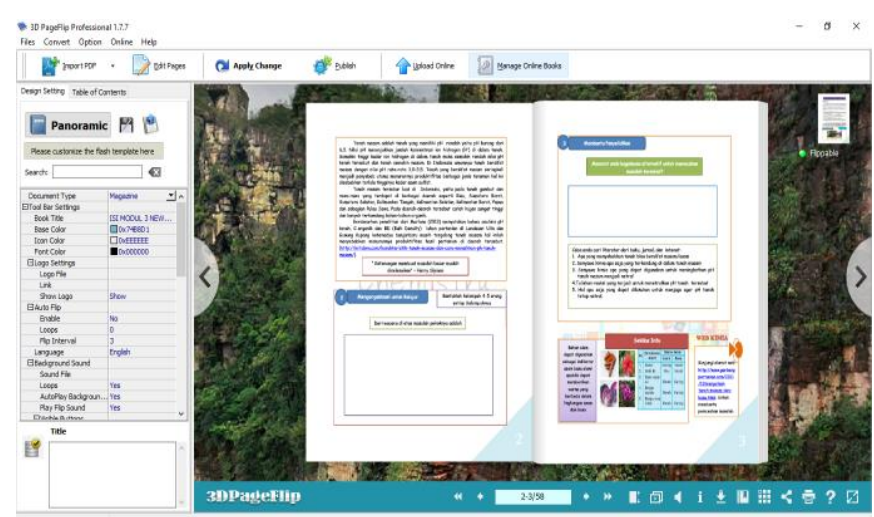

Figure 1. e-module with a wetland environment-based PBL model

The Test of Between-Subjects Effects test results with MANOVA showed that the $F$ value for critical thinking skills was 54,788 with $p=0.00<0.05$. As for the caring attitude towards the environment, the $\mathrm{F}$ value is equal to 132.726 with $\mathrm{p}$-value $=0.00<0.05$. From these results also obtained the MSE value for critical thinking skills of 0.009 and the MSE value for environmental care attitudes of 0.008 . For a summary of the results of the Test of Between-Subjects Effects can be seen in Table 2 below.

Table 2. Tests of Between-Subjects Effects

\begin{tabular}{llll}
\hline Source & Dependent Variable & F & Sig. \\
\hline Corrected & Critical Thinking Skills & 54.788 & .000 \\
Model & Environmental Care Attitude & 132.726 & .000 \\
& Critical Thinking Skills & 4231.557 & .000 \\
Intercept & Environmental Care Attitude & 4553.700 & .000 \\
& Critical Thinking Skills & 54.788 & .000 \\
Class & Environmental Care Attitude & 132.726 & .000 \\
& Critical Thinking Skills & & \\
Error & Environmental Care Attitude & & \\
\multirow{5}{*}{ Total } & Critical Thinking Skills & & \\
Corrected & Environmental Care Attitude & & \\
Total & Critical Thinking Skills & & \\
\hline & Environmental Care Attitude & & \\
\hline
\end{tabular}

a. R Squared $=.454$ (Adjusted R Squared $=.445$ )

b. R Squared $=.668$ (Adjusted R Squared $=.663$ )

The first problem, based on the results of the MANOVA test in Table 1, shows that the value of $\mathrm{F}==$ 3798.463 with $p=0.00<0.05$. This means that there are differences in students' critical thinking skills and environmental care attitudes who use the e-module PBL model based on wetland environments and use textbooks commonly used in schools. Based on the average value of the normalized gain score, it shows that the average value of critical thinking skills in the experimental group, namely students who use the emodule PBL model based on a wetland environment, is 0.84 greater than the control group, namely the group of students who learn with the usual textbook at school of 0.66. The average result of the gain score for the environmental care attitude of the experimental group is 0.86 , greater than the control group, namely 0.61 . The difference in the average gain score indicates that the emodule PBL model based on the wetland environment positively affects the results of students' critical thinking skills.

For the second problem based on Table 2, the F value of students' critical thinking skills was 54.788 with $\mathrm{p}=0.00<0.05$. Thus, $\mathrm{H} 0$ is rejected, and $\mathrm{H} 1$ is accepted, so it can be concluded that there are differences in students' critical thinking skills who use the e-module PBL model based on wetland environments and use textbooks commonly used in schools. This can occur because students' critical thinking skills are greatly influenced by the e-module PBL model based on the wetland environment. Finally, for the third problem based on Table 2, the F value of environmental care is equal to132.726 where $p=0.00$ $<0.05$. Thus, $\mathrm{H} 0$ is rejected, and $\mathrm{H} 1$ is accepted, so it can be concluded that there are differences in environmental care attitudes of students who use the emodule PBL model based on wetland environments and use textbooks commonly used in schools. Again, this can occur because the environmental care attitude of students is greatly influenced by the e-module PBL model based on the wetland environment.

The learning process uses the e-module PBL model based on the wetland environment. Students are taught to be critical of the problems presented by solving problems through various strategies and tactics. In this way, students are expected to be able to apply their critical thinking skills in the learning process at school and life. The problems presented in the e-module are in the form of soil $\mathrm{pH}$ analysis, $\mathrm{C}$ organic and BD agricultural land in Ulin and Gunung Kupang, Banjarbaru municipalities which are classified as acid soils resulting in decreased productivity of agricultural products in the area, the acidity level of Banjarmasin river water has increased drastically and is of concern. $60 \%$ of South Kalimantan's peatlands are damaged. With the use of the e-module PBL model based on the wetland environment through teacher guidance as a facilitator, students are trained to think deeply to construct knowledge so that they can understand a concept correctly. Problem-based learning is in accordance with constructivist learning theory, which facilitates students to develop their critical thinking skills. Contextual problems in problem-based learning through the e-module PBL model based on a wetland environment train students to analyze information to correct related concepts.

Unstructured problems help students develop various analysis and problem-solving solutions (Temel, 2014). Through the e-module learning of the PBL model based on the wetland environment, students share and express arguments and have further possibilities to 
correct misunderstandings of concepts while discussing the problems at hand (Loyens et al., 2015). Learning emodule PBL model based on wetland environments uses issues that are often encountered every day so that the learning process becomes meaningful and makes it easier for students to build correct concepts.

This is supported by research (Jaenudin et al., 2017; Sari et al., 2019; Seruni et al., 2020; Sujanem et al., 2020) PBL-based e-modules in the learning process provide an in-depth understanding of the cognitive, affective, and psychomotor domains that support improving critical thinking and problem-solving skills that improve student learning outcomes. In addition, participants have insight into the wetland environment, which is a local advantage in South Kalimantan. In accordance with (Annafi \& Agustina, 2018; Septiani et al., 2020) states the same thing that the implementation of PBL in the learning process that raises local wisdom and potential, besides being able to improve learning outcomes, can also foster students' attitudes and character towards the surrounding environment. and the psychomotor domain that supports improving critical thinking and problem-solving skills that will enhance student learning outcomes.

In addition, participants have insight into the wetland environment, which is a local advantage in South Kalimantan. In accordance with (Annafi \& Agustina, 2018; Septiani et al., 2020) states the same thing that the implementation of PBL in the learning process that raises local wisdom and potential, besides being able to improve learning outcomes, can also foster students' attitudes and character towards the surrounding environment. and the psychomotor domain that supports improving critical thinking and problem-solving skills that improve student learning outcomes. In addition, participants have insight into the wetland environment, which is a local advantage in South Kalimantan. In accordance with (Annafi \& Agustina, 2018; Septiani et al., 2020) states the same thing that the implementation of PBL in the learning process raises local wisdom and potential besides being able to improve learning outcomes foster students' attitudes and character towards the surrounding environment.

\section{Conclusion}

Based on the results of research and discussion, it can be concluded that there are differences in critical thinking skills and environmental care attitudes of students who use the PBL e-module model based on the wetland environment and use textbooks commonly used in schools. There are differences in students' critical thinking skills who use the PBL e-module model based on the wetland environment and use textbooks widely used in schools. There are differences in the environmental care attitude of students who use the PBL model e-module based on the wetland environment and use textbooks that are widely used in schools. The recommendations from this study are to conduct further research on PBL e-modules based on wetland environments using other materials/topics and conduct e-module research with other models and methods.

\section{References}

Ageorges, P., Bacila, A., Poutot, G., \& Blandin, B. (2014). Some Lessons from a 3-Year Experiment of Problem-Based Learning in Physics in a French School of Engineering. American Journal of Educational Research, 2(8), 564-567. doi: doi: https://doi.org/10.12691/education-2-8-1

Anantyarta, P., \& Sari, R. L. I. (2017). Keterampilan Kolaboratif dan Metakognitif melalui Multimedia berbasis Means Ends Analysis Collaborative and Metacognitive Skills Through Multimedia Means Ends Analysis Based. Jurnal Biologi Dan Pembelajaran Biologi, 2(2), 33-43. doi: https://doi.org/10.32528/bioma.v2i2.821

Annafi, N., \& Agustina, S. (2018). Pengembangan Model Pembelajaran Project Based Learning (PBL) Berbasis Kearifan Lokal Untuk Mempersiapkan Calon Pendidik Yang Berbudaya. Quantum: Jurnal Inovasi Pendidikan Sains, 9(1), 1-10. DOI: http://dx.doi.org/10.20527/quantum.v9i1.4854 [Indonesian]

Aufa, M., Iriani, R., Saadi, P., Hasbie, M., Fitri, M., \& Yunita, A. (2020). Module Development with Problem Based Learning (PBL) Model Based on Environmental Wetland to Increase Students' Learning Outcomes. JKPK (Jurnal Kimia dan Pendidikan Kimia), 5(2), 201-210. doi:http://dx.doi.org/10.20961/jkpk.v5i2.40451.

Bao, W. (2020). COVID-19 and online teaching in higher education: A case study of Peking University. Hum Behav \& Emerrg Tech, 2(March), 113-115. doi: https://doi.org/10.1002/hbe2.191

Basilaia, G., \& Kvavadze, D. (2020). Transition to Online Education in Schools during a SARS-CoV2 Coronavirus (COVID-19) Pandemic in Georgia. Pedagogical Research, 5(4), em0060. https://doi.org/10.29333/pr/7937.

Batdi, V. (2014). The effects of a problem based learning approach on students' attitude levels: A metaanalysis. Educational Research Reviews, 9(9), 272276. doi: https://doi.org/10.5897/ERR2014.1771

Birgili, B. (2015). Creative and critical thinking skills in problem-based learning environments. openaccess.mef.edu.tr. 
http:/ /openaccess.mef.edu.tr/xmlui/handle/20.5 $00.11779 / 754$

Efendioglu, A. (2015). Problem-Based Learning Environment In Basic Computer Course: PreService Teachers Achievement And Key Factors For Learning. Journal of International Education Research (JIER), 11(3), 205-216. doi: https://doi.org/10.19030/jier.v11i3.9372.

Facione, P. (2015). Critical Thinking: What It Is and Why It Counts. Insight Assessment.

Fahim, M., \& Masouleh, N. S. (2012). Critical Thinking in Higher Education: A Pedagogical Look. Theory and Practice in Language Studies, 2(7), 1370-1375. doi: https://doi.org/10.4304/tpls.2.7.1370-1375

Fahim, M., \& Pezeshki, M. (2012). Manipulating Critical Thinking Skills in Test Taking. International Journal of Education, 4(1), 153-160. doi: https://doi.org/10.5296/ije.v4i1.1169

Goldschmidt, K. (2020). The COVID-19 pandemic: Technology use to support the wellbeing of children. Journal of Pediatric Nursing, $x x x x, 1-3$. doi: https://doi.org/10.1016/j.pedn.2020.04.013

Gunawan, G., Suranti, N. M. Y., \& Fathoroni, F. (2020). Variations of Models and Learning Platforms for Prospective Teachers During the COVID-19 Pandemic Period. Indonesian Journal of Teacher Education, 1(2), 61-70. Retrieved from https://journal.publicationcenter.com/index.php/ijte/article/view/95.

Hasbie, M., Rusmansyah, \& Istyadji, M. (2018). Penerapan Model Project Based Learning (PJBL) Dalam Pembelajaran Sistem Koloid Untuk Meningkatkan Self Efficacy Dan Kemampuan Berpikir Kritis Peserta Didik. Journal of Chemistry And Education, 2(2), 50-56. Retrieved from: http://itam.ulm.ac.id/index.php/jcae/article/vie $\underline{w} / 116$ [Indonesian]

Hastuti, P. W., Nurohman, S., \& Setianingsih, W. (2018). The Development of Science Worksheet Based on Inquiry Science Issues to Improve Critical Thinking and Scientific Attitude. Journal of Physics: Conference Series, Conf. Seri, 1-8. doi: https://doi.org/10.1088/17426596/1097/1/012004

Ibrahim, I., Aminudin, N., Andrew, M., \& Suleiman, Y. (2012). Education for Wetlands: Public Perception in Malaysia. Procedia-Social and Behavioral Sciences, 42, 159-165. doi: https://doi.org/10.1016/j.sbspro.2012.04.177

Imanda, R., Khaldun, I., \& Azhar. (2017). Pengembangan Modul Pembelajaran Kimia SMA Kelas XI Pada Materi Konsep Dan Reaksi-Reaksi Dalam Larutan Asam Basa. Indonesian Journal of Science Education, 5(2), 41-48. doi: https://doi.org/10.24815/jpsi.v5i2.9816
[Indonesian]

Jaenudin, A., Baedhowi, \& Murwaningsih, T. (2017). The Effectiveness of the E-Module of Economics Learning on Problem-Based Learning used to Improve Students' Learning Outcomes. Advances in Social Science, Education and Humanities Research, 158, 30-36. doi: https://doi.org/10.2991/ictte$\underline{17.2017 .32}$

Klegeris, A., Bahniwal, M., \& Hurren, H. (2013). Improvement in Generic Problem-Solving Abilities of Students by Use of Tutor-less Problem-Based Learning in a Large Classroom Setting. 12, 73-79. doi: https://doi.org/10.1187/cbe.12-06-0081

Kurniawan, W., Pujaningsih, F. B., Latifah, \& Latifah, N. A. (2018). Analisis Kebutuhan Mahasiswa Terhadap Bahan Ajar Sebagai Acuan Pengembangan Modul Fisika Gelombang Bola dan Tabung. Jurnal EduFisika, 3(1), 17-23. doi: https://doi.org/10.22437/edufisika.v3i01.5805 [Indonesian]

Lestari, D., \& Projosantoso, A. (2016). Pengembangan media komik IPA model PBL untuk meningkatkan kemampuan berfikir analitis dan sikap ilmiah. Jurnal Inovasi Pendidikan IPA, 2(2), 145-155.

doi:

https://doi.org/10.21831/jipi.v2i2.7280.

[Indonesian]

Loyens, M. M., Jones, S. H., Mikkers, J., \& Gog, T. Van. (2015). Problem-based learning as a facilitator of conceptual change. Learning and Instruction, 38, 34-42.

doi: https://doi.org/10.1016/j.learninstruc.2015.03.00 2

Naparin, M., Rusmansyah, \& Almubarak. (2020). Identification of Critical Thinking Skills and Self Efficacy Students of Class XI IPA High School Of Banjarmasin City In Reaction Rate. Journal of Chemistry And Education, 3(3), 106-117.

Prihartiningsih, Zubaidah, \& Kusairi. (2016). Prihartiningsih-1053-1062.pdf. Pros, Semn(1), 10531062.

Redhana, I. W. (2019). Mengembangkan Keterampilan Abad Ke-21 Dalam Pembelajaran Kimia. Jurnal Inovasi Pendidikan Kimia, 13(1), 2239-2253. retrieved ftom: https://journal.unnes.ac.id/nju/index.php/JIPK Larticle/view/17824 [Indonesian]

Rosnanda, D., Sarwanto, \& Aminah, N. S. (2017). Pengembangan Modul Pembelajaran Berbasis Masalah Pada Materi Litosfer Untuk Meningkatkan Keterampilan Berpikir Kritis Siswa SMP. Jurnal Inkuri, 6(3), 141-152. doi: https://doi.org/10.20961/inkuiri.v6i3.17866 [Indonesian]

Sari, Ellizar, E., \& Azhar, M. (2019). Development of 
problem-based learning module on electrolyte and nonelectrolyte solutions to improve critical thinking ability. IOP Conf. Series: Journal of Physics, Conf. Seri, 1-9. doi: https://doi.org/10.1088/17426596/1185/1/012146

Sari, R. D. M., \& Rachmawati, L. (2017). Pengembangan Modul Pembelajaran Berbasis Problem Based Learning Pada KD Mendeskripsikan Bank Sentral, Sistem Pembayaran dan Alat Pembayaran dalam Perekonomian Indonesia Kelas X IIS SMAN 1 Krembung. Jurnal Pendidikan Ekonomi, 5(3). doi: https://doi.org/10.26740/jupe.v5n3.p\%p [Indonesian]

Septiani, F., Sriyati, S., \& Amprasto. (2020). The Implementation of Teaching Materials Based on Local Agricultural Wisdom in Binjai to Improve Student Environmental Literacy. Advances in Social Science, Education and Humanities Research, 399, 80-85. doi: https://doi.org/10.2991/assehr.k.200130.086

Seruni, R., Munawaroh, S., Kurniadewi, F., \& Nurjayadi, M. (2020). Implementation of emodule flip PDF professional to improve students' critical thinking skills through problem based learning. Journal of Physics: Conference Series, 1521, 1-6. doi: https://doi.org/10.1088/17426596/1521/4/042085

Sujanem, R., Suwindra, I. N. P., \& Suswandi, I. (2020). The Effectiveness Of Problem-Based Interactive Physics E-Module On High School Students' Critical Thinking. IOP Conf. Series: Journal of Physics, 1503, 1-11. doi: https:// doi.org/10.1088/17426596/1503/1/012052

Sumarni, W., Supardi, K. I., \& Widiarti, N. (2018). Development of assessment instruments to measure critical thinking skills. IOP Conf. Series, Materials, 1-12. doi: https://doi.org/10.1088/1757899X/349/1/012066

Sun, L., Tang, Y., \& Zuo, W. (2020). Coronavirus pushes education online (p. 687).

Suryanti, Arifin, I. S. Z., \& Baginda, U. (2018). The Application of Inquiry Learning to Train Critical Thinking Skills on Light Material of Primary School Students. Journal of Physics: Conference Series, Conf. Seri, 1-7. doi: https:// doi.org/10.1088/17426596/1108/1/012128

Temel, S. (2014). The effects of problem-based learning on pre-service teachers' critical thinking dispositions and perceptions of problem-solving ability. South African Journal of Education, 34(1), 120.
Ulfah. (2020). Identifikasi Kemmapuan Critical Thinking Kelas 9 SMPN Pada Materi IPA di Kotabaru. Indonesian Journal of Natural Science Education ( IJNSE ), 03(10), 257-264. doi: https://doi.org/10.31002/nse.v3i1.880

Vlasta, R., \& Jan, Š. (2011). Informatics In 21 Th Century - Reflection Of Changes. Journal of Technology and Information, 3(2), 10-13. doi: https://doi.org/10.5507/itie.2011.018

Wilson, K. (2016). Critical reading, critical thinking: Delicate scaffolding in English for Academic Purposes ( EAP ). Thinking Skills and Creativity, 22, 256-265. doi: https://doi.org/10.1016/j.tsc.2016.10.002

Yarid, H., \& Ariswan. (2016). Pengembangan Perangkat Pembelajaran Fisika Problem Based Learning Melalui Kegiatan Fieldtrip pada Materi Energi. Jurnal Inovasi Pendidikan IPA, 2(1), 24-34. doi: https://doi.org/http://dx.doi.org/10.21831/jipi. v2i1.8374

Yunita, A., \& Aufa, M. N. (2020). Wetland environment as learning resource using CTL approach to improve critical thinking in $21^{\text {st }}$ century. Journal of Physics: Conference Series, 1422(1). doi: https://doi.org/10.1088/17426596/1422/1/012030

Zaini, M., Amintarti, S. R. I., \& Ajizah, A. (2020). Student Worksheets Microbial Concepts Based On Urban Wetlands to Improve Critical Thinking Skills at High School Levels. Bio-Inoved: Jurnal Biologi-Inovasi Pendidikan, 2(1), 53-63. doi: https://doi.org/10.20527/bino.v2i1.8154

Zekri, Ganefri, \& Anwar, M. (2020). Pengembangan Modul Pembelajaran Berbasis Proyek pada Mata Pelajaran Simulasi dan Komunikasi Digital SMK. Pedagogi: Jurnal Ilmu Pendidikan, 20(1), 33-42. doi: https://doi.org/10.24036/pedagogi.v20i1.827

Zulmaulida, R., Wahyudin, \& Dahlan, J. A. (2018). Watson-Glaser' s Critical Thinking Skills WatsonGlaser' s Critical Thinking Skills. IOP Conf. Series: Journal of Physics, Conf. Seri, 1-7. doi: https://doi.org/10.1088/1742$\underline{6596 / 1028 / 1 / 012094}$ 